\title{
HiPÓTESE SOBRE A NOÇÁO DE PREFÁCIO EM ÉDOUARD GLISSANT
}

\author{
Alcione Correa Alves ${ }^{1}$
}

\begin{abstract}
Resumo: Este texto visa a estabelecer linhas iniciais a uma apropriação da premissa do Caribe como prefácio às Américas, conforme o ensaio Introduction à une poétique du Divers, de Édouard Glissant, compreendendo-o em um quadro de pensamento negro americano. A apropriaçáo da premissa de Glissant almeja propor bases a uma ferramenta metodológica, fundamentada na centralidade epistemológica do lugar, subsidiando análises literárias a respeito de um corpus de literaturas afroamericanas. Este texto, inicialmente, parte da hipótese de que qualquer literatura nacional (inclusive, a literatura afro-brasileira) pode ser tomada, de modo econômico, como prefácio a um corpus mais amplo de literaturas afro-americanas.
\end{abstract}

Palavras-chave: Édouard Glissant: teoria. Prefácio. Lugar. Literaturas afro-americanas. Literaturas amefricanas.

\section{INTRODUÇÃo}

Em se tratando de pesquisas científicas versando sobre literaturas afroamericanas, conforme suas tendências observáveis na comunidade científica dos Estudos Literários, no Brasil ${ }^{2}$, mostram-se relevantes as recentes condições de emergência à circulação de pensamento negro americano, no Brasil, mediante:

${ }^{1}$ Professor associado I na Universidade Federal do Piauí (UFPI), Teresina, PI - Brasil: nessa universidade, além de desempenhar atividades de graduação (CLE/UFPI) e de pós-graduação (PPGEL/ UFPI), coordena o Projeto de Pesquisa e Extensão Teseu, o labirinto e seu nome, assim como o Grupo DGP/CNPq Amefricanidades: lugar, diferença e violência; ademais, atualmente, é membro do Grupo DGP/CNPq Núcleo de Estudos e Pesquisas É’lééko. (D) https://orcid.org/0000-0002-8405-430X. E-mail: alcione@ufpi.edu.br.

2 Ao longo de todo o texto, todas as referências ao conceito de comunidade científica se encontram conforme sua definição em KUHN, 1998, p. 67-76.

https://doi.org/10.1590/0101-3173.2022.v45esp.12.p207 
traduções de textos ainda indisponíveis em português brasileiro ${ }^{3}$, além de retraduçôes atualizadas de obras antes pouco disponíveis, com menor circulação; publicaçôes coligindo obras esparsas que, doravante, se tornam disponíveis na forma de novas edições organizadas ${ }^{4}$; iniciativas de investigação, em níveis de graduação e pós-graduação, ademais de docência, projetos de pesquisa certificados e iniciativas de comunicação de ciência, com aproveitamento de canais universitários oficiais (emissoras públicas de rádio e televisão), assim como de possibilidades recentemente abertas por redes sociais.

$\mathrm{O}$ acesso a esse corpus de pensamento negro, sobretudo mediante novas ediçôes de textos ensaísticos e de textos literários, em conjunto a sua circulação pública, tem propiciado não apenas os avanços supracitados como, particularmente, as condiçóes à proposição de um problema, acerca da natureza da relaçáo entre lugar e conhecimento, nos seguintes termos iniciais: supondo que essa circulação recente de pensamento negro americano, a um público mais amplo, implique um avanço no conhecimento produzido a seu respeito, qual a relevância do lugar dessas(es) sujeitas(os) - que passam a circular esse pensamento - no conhecimento produzido sob tais condiçôes?

Os questionamentos construídos por Gayatri Chakravorty Spivak (2010) proporcionam uma pergunta sobre o lugar de onde enunciam as literaturas que investigamos ${ }^{5} \mathrm{ou}$, mais especificamente, literaturas que, em conformidade a alguns pressupostos vigentes, ao investigá-las, as racializamos.

[...] o subalterno é alvo da violência epistêmica, se constituindo como o Outro do discurso colonial, que ora está por sua própria conta, ora deve estar sob tutela. [...] o subalterno não é aquele que tem voz, mas aquele que é continuamente falado pelo desejo do outro.

\footnotetext{
${ }^{3}$ Como exemplos relevantes dessa tendência, cumpre ressaltar: HILL COLLINS, 2019; ademais de traduçóes recentes, em publicaçōes organizadas, do pensamento de bell hooks (pela Elefante), de Toni Morrison (pela Companhia das Letras) e de Angela Davis, englobando retraduçôes e traduçôes inéditas (pela Boitempo).

${ }^{4}$ A fim de ilustrar essa tendência, cumpre destacar: GONZÁLEZ, 2018; além dos três volumes da coleção Pensamento Preto: Epistemologias do Renascimento Africano, publicados pela mesma Editora Filhos da África, em 2018.

5 O lugar constitui uma categoria mobilizadora do pensamento de Glissant: "Viver a totalidademundo a partir do lugar que é o nosso, é estabelecer relação e não consagrar exclusão." (GLISSANT, 2005 , p. 80 apud SOUZA, 2019, p. 25). Nesse "viver a totalidade-mundo a partir do lugar que é o nosso", busca-se um exame preliminar de algumas das condições a essa solicitação de Glissant, conforme as regras atinentes ao atual momento da comunidade científica dos estudos literários, no Brasil; nisso consiste o objetivo, subjacente, deste artigo, assim como do trabalho coletivo do Projeto Teseu, o labirinto e seu nome, em suas atuais iniciativas de pesquisa e de extensão.
} 
Uma forma bastante profícua de subalternização também está no modo e nas escolhas discursivas nas quais investimos quando elegemos pares teóricos ou conceitos para diálogo. (SOUZA, 2018, p. 28).

A hipótese de Lívia Natália de Souza, de um subalterno falado pelo desejo do outro, como um dos modos possíveis de receber e tratar da indagação proposta por Spivak, subalterno este tomado como alvo da violência epistêmica (ao que a escolha de alvo apresenta, em seu sentido bélico, uma devida circunscrição à violência), permite elaborar um problema legítimo, a partir de duas premissas: a) a agência dessas(es) sujeitas(os) em condição de subalternidade; e b) a subalternidade compreendida não como essência, mas enquanto condição atribuída a sujeitas(os) e coletividades humanas ${ }^{6}$. Referências como a de Spivak e a de Souza fornecem subsídios iniciais a um exame da enunciação de sujeitas(os) tomando, como pedra de toque ao restante do texto, a centralidade epistêmica do lugar desde o qual essas(es) sujeitas(os), em condição de subalternidade, enunciam; e desde o qual se abre a possibilidade, a uma ciência dedicada à investigação do fato literário, de compreender a essas(es) sujeitas(os), investigando as relaçóes entre sua agência e sua enunciação. Esse problema se mostra relevante ao exame de práticas circulantes na comunidade científica dos Estudos Literários, no Brasil, à medida que enseja o desenho e o tratamento de um problema metodológico, atinente a essa comunidade, na forma da seguinte pergunta: como compreender, cientificamente, a complexidade própria às literaturas afro-americanas, sem reduzi-las a categorias exógenas a elas?

Isso posto, este texto visa a uma apropriação da premissa do Caribe como prefácio às Américas, conforme enunciada no ensaio Introduction à une poétique du Divers, de Édouard Glissant (1996), compreendendo-o em um quadro mais amplo de pensamento negro americano contemporâneo. A apropriação da premissa de Glissant proporá bases a uma ferramenta metodológica, fundamentada na centralidade epistemológica do lugar como meio para uma compreensão das literaturas afro-americanas, subsidiando análises literárias desse corpus delimitado, no âmbito da comunidade científica dos Estudos Literários, no Brasil.

\footnotetext{
${ }^{6}$ Sobre esse ponto, no tocante a textos circulantes na comunidade científica dos estudos literários, no Brasil, recomenda-se o capítulo de Hall, "Nascimento e morte do sujeito moderno" (HALL, 2006), assim como o capítulo "Onde está o 'sujeito'?" (HALL, 2016) e, mais recentemente, o capítulo "Negritude pós-moderna” (hooks, 2019), como leituras iniciais à complexidade de uma essencialização das identidades de nossos Outros.
} 
Como procedimento metodológico próprio a este texto, o exame das passagens de Introduction à une poétique du Divers (doravante, IPD), assim como de textos correlatos de Glissant, visará a um mapeamento de componentes peculiares à noção de prefácio, de modo a desenvolver o argumento da centralidade epistemológica do lugar, assinalando, destarte, algumas das contribuiçôes de Glissant ao problema central. ${ }^{7}$ A respeito desse percurso metodológico relativo à noção de prefácio, cumpre ressaltar a relevância do tratamento de algumas de suas componentes, sob dois princípios: a) as discussões ora estabelecidas, em um marco de pensamento negro contemporâneo, serão conduzidas à luz de um paradigma de interseccionalidade - aqui, tomado como "[...] um paradigma alternativo que [...] pode constituir uma parte importante da epistemologia feminista negra" (HILL COLLINS, 2019, p. 403); b) tais discussōes objetivam subsidiar uma posterior elaboração de indicadores e índices adequados à fundamentação de análises literárias, em pesquisas científicas empíricas, no âmbito da comunidade científica dos Estudos Literários, no Brasil.

Para tratar do problema assim construído, este texto parte da hipótese de que qualquer literatura nacional ${ }^{8}$ (inclusive, a literatura afro-brasileira, e, no limite, qualquer obra literária afro-americana) pode ser tomada, de modo econômico, como prefácio a um corpus mais amplo de literaturas afroamericanas, compreendidas à luz da noção de Divers (GLISSANT, 1997) ${ }^{9}$; espera-se, com o desenvolvimento desse argumento, a formulação de bases a investigaçóes posteriores, propondo pesquisas em que cada literatura nacional

\footnotetext{
${ }^{7} \mathrm{O}$ termo componente (ou, por vezes, dimensäo), ao longo deste artigo, parte de usos metodológicos no tocante ao tratamento de conceitos ou, especificamente, o princípio de que "[...] para la determinación de 'variables' capaces de medir objetos complejos, hay que seguir casi siempre un proceso más o menos típico. Este proceso, que permite expresar los conceptos en términos de índices empíricos, comprende cuatro fases principales: la representación literária del concepto, la especificación de las dimensiones, la elección de los indicadores observables, y la síntesis de los indicadores o elaboración de los índices." (LAZARSFELD, 1973, p. 36, grifos do autor).

${ }^{8}$ Ao cogitar as regras atinentes à comunidade científica sobre o tema, convém assinalar que a opção por uma noção de literatura nacional segue sua definição, no início do capítulo 36 de $D A$, definição esta adotada aos fins deste texto, desde seu resumo e ao longo de seu desenvolvimento: "Diz-se que há literatura nacional quando uma comunidade contestada em sua existência coletiva tenta reunir as razōes desta existência." (GLISSANT, 2001).

9 No que tange à comunidade científica dos Estudos Literários, no Brasil, não se pode negligenciar o debate terminológico em torno dos termos negra e afro-brasileira. Para uma primeira apreensão do tema, consulte-se o artigo "Literatura afro-brasileira: um conceito em construçẫo" (DUARTE, 2011), assim como o capítulo "Literatura negra, literatura afro-brasileira: como responder a polêmica?" (FONSECA, 2006).
} 
traga, potencialmente, a possibilidade de ser tomada como prefácio a um conjunto mais amplo de literaturas afro-americanas.

\section{DA CENTRALIDADE EPISTEMOLÓGICA DO LUGAR}

Ce paysage américain qu'on retrouve dans une petite île ou sur le continent me paraît toujours aussi irrué. Et c'est de là que me vient probablement le sentiment que j'ai toujours eu d'une sorte d'unité-diversité, d'une part des pays de la Caraïbe et d'autre part l'ensemble des pays du continent américain. En ce sens, la Caraïbe m'a toujours paru être une sorte de préface au continent. Au XVIème et XVIIème siècles, on apelait mer Caraïbe mer du Pérou, alors que le Pérou est de l'autre côté du continent et qu'il n'y a aucune relation possible. Il y a avait là une espèce de liaison entre ce qu'il faut laisser derrière soi et ce qu'il faut entreprendre de connaître. (GLISSANT, 1996, p. 12). ${ }^{10}$

Glissant aproxima, inicialmente, o território do Caribe insular a um conjunto mais amplo, formado pelo continente americano; no arquipélago, a paisagem desempenha papel primordial, visto que estabelece uma base intuitiva mediante a expressão Et c'est de là que me vient probablement le sentiment que j'ai toujours eu (E é disso, provavelmente, que vem um sentimento que sempre tive) a uma medida entre o Caribe e o conjunto do continente americano.

Dentro da análise, duas recorrências de falloir (ser necessário, ser preciso) no gesto de conhecimento do lugar americano, assim como na relação com outros lugares americanos possíveis: ce qu'il faut laisser derrière (o que é preciso

10 "Essa paisagem americana que reencontramos no continente ou em uma pequena ilha me parece, sempre e por toda parte, 'irrué. E é disso, provavelmente, que vem um sentimento que sempre tive de uma espécie de unidade-diversidade, por um lado, dos países do Caribe, e por outro lado, do conjunto dos países do continente americano. Nesse sentido, o Caribe sempre me pareceu ser uma espécie de prefácio do continente americano. Uma vez mais as palavras falam, e eu gostaria de lembrar-lhes que nos séculos XVI e XVII, chamava-se o mar do Caribe de mar do Peru. Ora, o Peru está do outro lado do continente e não existe nenhuma relação possível. Já se havia então compreendido que existe ali uma espécie de introdução ao continente, uma espécie de elo entre o que é preciso deixar atrás de si e o que é preciso dispor-se a conhecer." (GLISSANT, 2005, p. 14-15). Doravante, todas as traduçôes de passagens de IPD recorrerão à tradução de Enilce Albergaria Rocha, publicada pela Editora da UFJF, tradução esta responsável, em larga medida, pela circulaçẫo do pensamento de Glissant na comunidade científica dos estudos literários, no Brasil, notadamente nos domínios da Teoria Literária e da Literatura Comparada, permitindo investigaçóes a formular problemas modelares, de sorte a relacionar Glissant a um quadro mais amplo de pensamento circulante nessa comunidade, nos anos 2000 (no qual identificamos a circulação, por exemplo, da tradução de O Atlântico negro, de Paul Gilroy, assim como de obras de Stuart Hall, de Néstor García Canclini e de Homi K. Bhabha, dentre as mais recorrentes na formulação de problemas modelares em investigaçōes empíricas). 
deixar atrás de si) no gesto de se lançar ao conhecimento do lugar americano; e ce quil faut entreprendre de connaître (o que é preciso se dispor a conhecer) nesse gesto, denotando uma necessidade de levar a termo um conhecimento que náo se dá por si próprio, apenas pela partilha do lugar, mas que, desde esse lugar, necessita ser buscado, examinado e construído - daí os usos de entreprendre (nesse sentido: se dispor a) e de laisser derrière (deixar, deixar atrás), esta última locução verbal nos exigindo um deslocamento de uma posição inicial aparentemente confortável, mas, em última instância, tautológica. Conhecer o lugar americano, em uma perspectiva mais ampla (continent: o continente), desde nosso lugar americano, que partilha algo desse sentido americano, supóe deslocamento e abertura a outros sentidos possíveis desse lugar americano. ${ }^{11}$

Em texto posterior, Glissant retoma e amplia, tomando, dessa vez, o Haiti como possível prefácio (em seu texto, point focal: ponto focal) ao Caribe e, se aceitamos a extensão proposta na premissa, ao continente americano. A imagem do Mar do Peru é retomada nessa segunda formulação:

Et puis, il faudrait aussi réfléchir au rôle, à la fonction de l'archipel vis-àvis des Amériques. L'archipel est une préface du continent, on y passait pour accéder aux Amériques et d'ailleurs, au XVIème siècle, la Mer des Antilles était appelée Mer du Pérou, alors que le Pérou est de l'autre côté du continent américain, parce que l'on passait par là, on débarquait et on traversait le continent pour arriver au Pérou. Et, par là, il y a un rôle sinon stratégique, du moins un rôle de conception du continent antillais qui passe par une médiation de la fonction de l'archipel Caraïbe. (GLISSANT, 2008, p. 30)..$^{12}$

\footnotetext{
${ }^{11}$ Ao longo da argumentação, essa componente do prefácio se faz presente, qual seja, a de uma intersecção (no texto de IPD, une espèce de liaison) entre o próprio do lugar qu’il faut laisser derrière (próprio a nossos devires mas, talvez, concessível ao exercício da partilha com outros lugares) e o que se abre a nosso conhecimento coletivo, nos demais lugares, em cada lugar quil faut entreprendre de connaître; a exigência de ce qu'il faut laisser derrière, antes de reivindicar o abandono [do particular] do lugar em detrimento de um coletivo [universal], convida ao exercício de conhecimento do lugar americano, em uma operação na qual a locuçâo laisser derrière nos solicita deslocamento de nosso lugar rumo a outros lugares possíveis, com base em, ao menos, duas componentes ao prefácio: a) a operação de conhecimento, em sua natureza eminentemente coletiva, solicitando o deslocamento do lugar a outros lugares; b) a operação de conhecimento, como necessidade (ce qu’il faut), solicitando nossa dedicação a ela (o conhecimento, aqui, não como um dado mas como construção - por isso, não apenas connaître mas entreprendre de connaître).

${ }^{12}$ Portanto, nesse sentido, seria necessário, também, refletir acerca do papel, da função do Arquipélago (l'archipel, o Caribe) em relação ao conjunto das Américas. O arquipélago é um prefácio ao continente; passava-se por ele para aceder às Américas e, a esse respeito, no século XVI, o mar do Caribe era chamado Mar do Peru (ainda que o Peru se localize do outro lado do continente americano), porque se passava pelo mar do Caribe, ali desembarcando e atravessando o continente para chegar ao Peru. E, por tal razão, há um papel, senão estratégico, ao menos de concepção do continente antilhano, o qual passa por uma mediação da função do arquipélago caribenho (GLISSANT, 2008, p. 30, tradução nossa).
} 
Nessa nova recorrência do verbo falloir, Glissant aponta uma necessidade, de parte do pensamento caribenho, naquele contexto próprio à primeira década deste século, de empreender um exame do papel do Caribe em um conhecimento do lugar americano ${ }^{13}$ : essa formulação ao Caribe como prefácio às Américas apresenta [em conformidade às teorias circulantes no momento] o Caribe em seu caráter fragmentário, do que decorre a introdução de outra noção importante ao pensamento glissantiano, o Archipel. ${ }^{14}$ Em sua condição de deslocamento, o campo semântico da passagem, do fluxo, se

${ }^{13} \mathrm{O}$ que, talvez, se mostre possível mediante a tipologia de Wagley (a qual dialoga com a do próprio Glissant; a seu respeito, ver: GAZTAMBIDE-GEIGEL, 1996; GIRVAN, 1999), ao propor o Caribe como Afro-América ou, mais propriamente, "América das plantaçóes" (ideia presente, contemporaneamente, por exemplo, em KILOMBA, 2019). Disso não advém, necessariamente, uma reduçâo do lugar caribenho à plantação (um exame de uma história possível da literatura, na Guiana Francesa, poderia nos dizer algo distinto, conforme, por exemplo: SILVA-REIS, 2021), de tal modo que nossos devires-negros estariam fadados a entreprendre de connaître uma sucessão tautológica de plantaçóes, ao longo do território americano, contudo, antes, disso talvez decorra a) a legitimidade da plantação na base de nossa compreensão do lugar americano; b) a plantação se habilitando a um tropo a serviço de nossa compreensão desse lugar americano, à luz desse procedimento metodológico em três etapas (portando conosco o lugar, ao longo de nossa caminhada; deixando o lugar para trás; abrindo-se à experiência - imprevisível, pois estamos glissantianas(os) - de conhecimento dos lugares que se nos apresentam à frente).

${ }^{14}$ Constatam-se apropriaçôes da noção de l'archipel, em ciência literária, por exemplo, na expressão arquipélago textual, presente no livro Le Chant du Divers: introduction à la philopoétique d'Édouard Glissant, de Manuel Norvat (2015); este, por sua vez, recupera a expressão encontrada na obra de JeanLouis Joubert, Édouard Glissant (2005). Quanto aos usos e apropriaçóes de Glissant pela comunidade científica dedicada à sua obra, cumpre ressaltar o desenvolvimento da noçáo de prefácio, previamente a IPD. Como primeiro exemplo, em artigo de Porto (2006), encontra-se um desenvolvimento tanto da paisagem quanto da noção mesma de prefácio, contemporaneamente ao lançamento da tradução de Rocha: "Segundo o referido autor, a primeira abordagem das Américas se faz a partir da leitura da paisagem. Ao contrário da paisagem européia, marcada pela ordem e pelo ritmo das estaçóes, a paisagem caribenha se caracteriza por sua abertura, por sua unidade-diversidade (GLISSANT, 1995, p.11-12). 'Prefácio do continente americano' (GLISSANT, 1995, p. 12), o Caribe oferece ao pesquisador vasto e rico material de análise.” (PORTO, 2006, p. 355-356). A noção de prefácio, em sua primeira formulação, já consta do ensaio "La pensée archipélique", presente em Poétique de la Relation, já em 1990, tendo sido antecedida semanas antes, na primeira página de um ensaio, intitulado "Beyond Babel" (GLISSANT, 1989), contemporâneo antecessor à publicação, em francês; nele, Glissant prevê uma formulação ao princípio ou, se assim se preferir, ao papel do prefácio em uma ideia do lugar americano: "The region has always been a place of encounter, of complicity, a 'preface' to the American continent"; como ponto pertinente, convém ressaltar que, assim como na redação de $I P D$, a ideia de um Caribe-prefácio se desenvolve em uma comparação entre duas concepçôes distintas de Mar (o Mediterrâneo e o do Caribe), associando o primeiro a uma ideia do Um, ao passo que o segundo, a uma ideia de Divers. Nesses termos iniciais, quiçá o Caribe tomado como um estudo de caso, comprobatório, à hipótese de uma Poética da Relação; uma vez aceito esse caso, nós nos habilitaríamos a propor juízos posteriores, acerca do lugar americano. Por fim, observemos que, no ensaio de 1989, tem-se um uso do prefácio ainda entre aspas, a "preface" to the American continent, em seu caráter de metáfora; no texto de $I P D$, esse caráter se mantém, mediante a expressão une sorte de préface, condicionantes estas suprimidas na formulação de 2008. Como proposta e justificativa de 
apresenta em duas ocorrências do verbo passer, a fim de demarcar o Caribe como passagem privilegiada ao adentramento do lugar americano, por via marítima, como um dos portos privilegiados de ingresso ao continente, no período do comércio negreiro estabelecido entre os séculos XVI a XIX: on y passait pour accéder aux Amériques (passava-se por ele, para aceder às Américas); on passait par là, on débarquait et on traversait le continent pour arriver au Pérou (passava-se pelo mar do Caribe, ali desembarcando e atravessando o continente para chegar ao Peru). ${ }^{15}$

A necessidade de examinar o Caribe nesses fluxos continentais, simultaneamente como lugar fragmentário em sua condição de arquipélago e como acesso privilegiado a esse continente e seus significados, exige, de parte de um pensamento particularmente situado entre o lugar e sua Relation, conhecer o lugar americano em uma perspectiva mais ampla (continent), em um cenário no qual o Caribe partilha algo desse sentido americano, ao supor deslocamento e abertura a outros de seus sentidos possíveis:

[...] Le rapport à la terre, rapport d'autant plus menacé que la terre de la communauté est alienée, devient tellement fondamental du discours, que le paysage dans l'oeuvre cesse d'être décor ou confident pour s'inscrire comme constituant de l'être. Décrire le paysage ne suffira pas. L'individu, la communauté, le pays sont indissociables dans l'épisode constitutif de leur histoire. Le paysage est un personnage de cette histoire. Il faut le comprendre dans ses profondeurs. (GLISSANT, 1997, p. 343). ${ }^{16}$

uma tradução ao ensaio "La pensée archipélique" e, em decorrência, de usos do prefácio em português brasileiro, consultar: SOUSA SOBRINHO, 2019, p. 70-74.

${ }^{15}$ Uma vez concebendo a retomada e desenvolvimento dessa imagem, em seu momento intelectual específico (segunda metade dos anos 2000, em um marco de pensamento apresentando, ao centro, teorias tributárias do que, hoje, delimitamos como Estudos Culturais), talvez valha a pena extrair, como consequência de nossas apropriaçóes de Glissant, no Brasil, investigaçóes nas quais se adota o alargamento dessa ideia de deslocamento, passando de um Caribe em sua importância logística a um Caribe percebido como ingresso do comércio negreiro às Américas, mediante um Mar como imaginário eminentemente de entrada às Américas (passagem, fluxo, encruzilhada, entre-lugar - compreendidos como conceitos ilustrativos dessa posição, na comunidade científica dos Estudos Literários). Com ponto de diálogo e, simultaneamente, avanço em relação a essa perspectiva, o desenvolvimento, contemporâneo, de investigaçóes centradas no lugar de sujeitas(os) negras(os) americanas(os) tem permitido reposicionar a violência ou, mais precisamente, a violência imputada a essas(es) sujeitas(os), nesse processo, visando a uma compreensão da relaçáo entre lugar e conhecimento e da agência dessas(es) sujeitas(os), sob tais condiçóes.

16 "A relação com a terra, a relação tanto mais ameaçada quanto a terra da comunidade estiver alienada, torna-se de tal modo fundamental ao discurso, que a paisagem na obra deixa de ser decoração ou confidente para se inscrever como constituinte do ser. Descrever a paisagem náo basta. $\mathrm{O}$ indivíduo, a comunidade, o país são indissociáveis no episódio constitutivo de sua história. A paisagem é um personagem desta história. É preciso compreendê-la em suas profundezas.” (GLISSANT, 2001). A 
Em tal cenário, a paisagem recebe uma função decisiva, quando, assim como na passagem anterior de IPD, Glissant recorre, em Le discours antillais (doravante, $D A$ ), ao que denomina la fonction du paysage (a função, o papel da paisagem), a fim de caracterizar os contornos de uma literatura nacional martinicana. Cumpre destacar, nessa citação, o lugar político da noção de paisagem (paysage), em Glissant, em uma delimitação preocupada com uma tendência a tomá-la como acessório (décor) às(aos) sujeitas(os) que nela vivem e a ela significam. ${ }^{17}$

Essa compreensão da ideia de prefácio, no pensamento de Glissant, estabelece diálogo com a hipótese de Linda Martín Alcoff (2016) sobre a importância epistemológica do lugar (e da identidade), em nossas práticas de produção e discussão de conhecimento, assim como em uma intervenção transformadora desse conhecimento em nossos contextos imediatos:

O projeto de decolonização epistemológica (e a mudança da geografia da razão) requer que prestemos atençáo à identidade social não simplesmente para mostrar como o colonialismo tem, em alguns casos, criado identidades, mas também para mostrar como têm sido silenciadas e desautorizadas epistemicamente algumas formas de identidade enquanto outras têm sido fortalecidas. Assim, o projeto de decolonização epistemológica presume a importância epistêmica da identidade porque entende que experiências em diferentes localizaçôes são distintas e que a localização importa para o conhecimento. (MARTÍN ALCOFF, 2016, p. 136). ${ }^{18}$

referida traduçáo, de Normelia Parise, comentada por Graciela Ortiz, consta do sítio Antologia de textos fundadores do comparatismo interamericano, publicação eletrônica cujo objetivo é a circulação, traduzida e comentada, de um corpus de ensaística latino-americana na comunidade científica dos estudos literários, no Brasil, notadamente nos domínios da Teoria Literária e da Literatura Comparada.

${ }^{17}$ Caso tomemos em conta que esse parágrafo se encontra em um contexto no qual, debatendo uma ideia de literatura nacional própria à compreensão de uma história literária na Martinica, parágrafo no qual se aponta a pertinência de uma poética realista em um tempo e um lugar específicos à literatura de França (do que resultaria o fracasso de recorrer a ela, apenas, como técnica de escrita, na tentativa de a reproduzir, nos contextos literários coloniais), a noção de paysage, inscrita no estar-no-mundo de sujeitas(os) caribenhas(os), opera em favor de uma política de escrita literária na qual l'individu, la communauté, le pays (o indivíduo, a comunidade, o país) são apresentados nos termos de um par conceitual l'Un-le Divers, par definitório do qual Glissant se serve. Ressalte-se o lugar da paysage na produção de conhecimento em ficcionalidades caribenhas, em um conhecimento desde esse lugar, assinalado por Glissant em seu exame do problema do real maravilhoso em Jacques Stéphen Alexis, em seu ensaio "Prolégomènes à un manifeste du réalisme merveilleux des Haïtiens" (ALEXIS, 2001); e em Alejo Carpentier, conforme seu prólogo ao romance El reino de este mundo (CARPENTIER, 1969), ambos citados por Glissant, ao final do mesmo parágrafo de $D A$.

${ }^{18}$ Quando Alcoff assinala “[...] como o colonialismo tem, em alguns casos, criado identidades [...] como têm sido silenciadas e desautorizadas epistemicamente algumas formas de identidade enquanto outras têm sido fortalecidas", eis o ponto de Edward W. Said, na introduçáo, assim como em suas análises de obras literárias de França dos séculos XIX e XX, em Cultura e imperialismo. Em publicação 
Martín Alcoff contribui à compreensão de uma epistemologia do lugar que toma, como tarefa, estabelecer um papel decisivo de seus fundamentos políticos ao centro de nossas produções, discussões e difusões de conhecimento; ao propor que nossos discursos não se emitem dans l'air (palavras ao vento), mas, precisamente, desde o lugar do qual os emitimos (GLISSANT, 1996, p. 29), são instauradas condiçôes a uma hipótese de interpretação de textos literários afro-americanos, em sua dupla dimensão de ficção e de ensaio, compreendidos como pensamento a respeito de seu lugar e de seu devir; tal pensamento, em seu exame, traz a possibilidade de ser pensado em rede ${ }^{19}$ (ou, na terminologia de Glissant, traz a Relation), com um campo mais amplo de pensamento americano dedicado à tarefa de discutir e tratar seus problemas, desde seus lugares e devires:

Le rapport est intense entre la nécessité et la réalité incontournables de la créolisation et la nécessité et la réalité incontournables du lieu, c'est-à-dire du lieu d'où l'on émet la parole humaine. On n'émet pas de paroles dans l'air, en diffusion dans l'air. Le lieu d'où on émet la parole, d'où on émet le texte, d'où on émet la voix, d'où on émet le cri, ce lieu-là est immense. (GLISSANT, 1996, p. 29). ${ }^{20}$

posterior, será possível desenvolver esse recurso a Said, em seu diálogo com um marco de pensamento americano contemporâneo, em algumas de suas possibilidades científicas e pedagógicas.

${ }^{19}$ Talvez, nesse ponto, a ideia de redes intelectuais, conforme o pensamento de Eduardo Devés-Valdés (2007; 2014), ofereça um aporte à hipótese de um marco de pensamento negro lido como pensamento em rede, caso acrescida da necessidade de aprimorar nossa ideia de intelectualidade, conforme preconiza Patricia Hill Collins (2019, p. 29-55). Perceber ficção afro-americana enquanto pensamento próprio a uma intelectualidade negra em rede, reconhecida em sua condição de producción y difusión del conocimiento (DEVÉS-VALDÉS, 2007, p. 30), “[...] remete a um procedimento de análise [...] em uma dupla dimensão: a de ficcionalidade, correspondente a nossos procedimentos correntes, no campo; a de ensaio, implicando pensar essas(es) sujeitas(os) enquanto sujeitas(os) cognoscentes - e, no interior do campo, reconhecendo-as(os) enquanto sujeitas(os) citáveis, comentáveis, dialogáveis, apropriáveis, convidáveis a nossas redes" (ALVES, 2018); conforme Souza, no início deste texto, a ideia de redes intelectuais negras implica um compromisso "[...] no modo e nas escolhas discursivas nas quais investimos quando elegemos pares teóricos ou conceitos para diálogo." (SOUZA, 2018, p. 28). A ideia de um pensamento negro contemporâneo, compreendido em rede, significa assumir nossos Outros em sua condição de sujeitas(os) cognoscentes, em sua agência, assim como sobre sua relação conosco na producción y difusión del conocimiento (DEVÉS-VALDÉS, 2007), de modo a supor a agência dessas(es) sujeitas(os) ao centro de sua produção de conhecimento; ademais, seguindo a pista de Devés-Valdés, deduz-se um princípio metodológico em que o pensamento racializado (de nossos Outros) pode ser lido enquanto redes intelectuais, requerendo, por parte de nossas investigaçóes científicas, mapeamento "[...] de cartografías intelectuales y/o eidéticas em seu pensamento, com todas implicações gnoseológicas daí decorrentes.” (ALVES, 2018).

20 "A relação é intensa entre a necessidade e a realidade incontornáveis da crioulização e a necessidade incontornáveis do lugar, isto é, do lugar de onde se enuncia a fala humana. Não emitimos palavras ao vento, soltas no ar. O lugar de onde emitimos a fala, de onde emitimos o texto, de onde emitimos a voz, de onde emitimos o grito, este lugar é imenso." (GLISSANT, 2005, p. 35-36). 
À hipótese de uma importância epistemológica do lugar ou, dito de outra forma, à possibilidade de produção, discussão e difusão de conhecimento desde um dado lugar de enunciação, necessita se seguir uma consequência: a possibilidade de contato entre o Divers de cada lugar (o que, em passagem anterior, Glissant assinalava como ce qu'il faut entreprendre de connaître), de modo a compreender intercâmbios e construçôes coletivas de conhecimentos tributários, também, de seus respectivos lugares. ${ }^{21}$ Em última instância, o prefácio visaria a salvaguardar a prerrogativa humana do conhecimento desde o lugar, ao estabelecer a pergunta explícita sobre os modos de produção e validaçáo do conhecimento sobre o lugar americano mais amplo, a partir do lugar de enunciação próprio a distintas(os) sujeitas(os) e coletividades americanas. Glissant convida a interpretar os textos negros caribenhos enquanto conhecimento desde um lugar caribenho, em sua tarefa de compreender seu Divers e suas possibilidades abertas de Relation:

Há também excelentes trabalhos desenvolvidos por epistemólogos continentais, como Hacking, e epistemólogos pós-coloniais tais como Mignolo, Glissant, Castro-Gómez, Patricia Williams, Jennifer Vest e, é claro, profícuos trabalhos desenvolvidos por epistemólogas feministas como Nelson, Potter, Lloyd, Campbell, Harding, Haraway, entre outras. Esses trabalhos pós-coloniais e feministas não cometem o erro de individualizar a agência epistêmica nem descontextualizar a verdade, mas mostram como as consideraçôes políticas podem, em alguns casos, ser legitimamente muito importantes para a justificaçáo. Isso nos proporciona um bom ponto de partida para o projeto epistemológico decolonial e reconstrutivista, desatrelando isso de um domínio que poderia ignorar a identidade e a localização dos sujeitos de conhecimento, mantendo, contudo, sua capacidade normativa. (MARTÍN ALCOFF, 2016, p. 134).

\footnotetext{
${ }^{21}$ Talvez, aqui, a primeira nota necessária acerca de um conhecimento que, supondo um lugar americano na tarefa de compreensão de outros lugares americanos possíveis, apresentaria bases habilitadas a prevenir uma perspectiva determinista ao conhecimento desde o lugar: no quadro de um pensamento negro americano, encontra-se a recorrência de propostas epistemológicas a conceber o caráter coletivo da produção e validação de conhecimento, ademais da predisposiçấo à abertura a outros lugares possíveis e outros conhecimentos deles resultantes sem, todavia, se reduzir esses modos de produção e validação de conhecimento a uma formulação relativista clássica; especificamente aos fins deste texto, seria possível propor que a prerrogativa de abertura a outros lugares possíveis, assim como a outros conhecimentos deles decorrentes, se mostra uma componente válida da noção de prefácio, habilitada a uma devida operacionalização da noçáo, nos termos ora debatidos. Uma componente assim formulada se revelaria uma chave de leitura apta ao exame de uma teoria do conhecimento dedutível da filosofia de Glissant, caso se observe a gama de noçôes que, interligadas em seu pensamento, constituem um campo semântico em torno desse princípio norteador do lugar em abertura a outros lugares possíveis: apenas a título de exemplo, convém assinalar certas noçôes, como rizoma, Tout-monde, Relation, a noção mesma de lieu (lugar; em português brasileiro, frequentemente: lugar de fala).
} 
A centralidade do lugar, em Glissant, se mostra situada em um marco de epistemologia contemporânea no qual, além de partilhar o problema de uma relação entre lugar e conhecimento, se dedica a compreender implicaçóes políticas atinentes aos processos de produção, discussão e validação de conhecimentos, a partir do lugar de sujeitas(os) cognoscentes. Note-se a estratégia de situar, ao menos, duas vertentes contemporâneas a uma tal apreciação do lugar, uma delas continental (na qual se situa Glissant, ao lado de teóricos quiçá mais circulantes em nossa comunidade científica, como, por exemplo, Walter Mignolo; e ao lado de um quadro de pensamento descolonial representado, aqui, por Santiago Castro-Gómez) e outra, versando sobre a centralidade de discussóes epistemológicas no seio de uma teoria feminista contemporânea. Nessa argumentação, pode-se depreender dois pontos comuns, partilhados por ambas as apreciaçóes do lugar: o cuidado em prevenir "o erro de individualizar a agência epistêmica", além de examinar "a identidade e a localização dos sujeitos de conhecimento".

Cabe observar um dado, na citação de Martín Alcoff, habilitado a contribuir com o problema central ao presente texto: sua preocupação constante, na apreciação de correntes epistemológicas americanas contemporâneas, de construir uma hipótese da centralidade do lugar "mantendo, contudo, sua capacidade normativa", assinalando-nos que quaisquer investigaçóes sobre o que se denomine epistemologias outras necessitam, como premissa, a prerrogativa de que, acerca dessas(es) sujeitas(os) compreendidas(os) como Outro, se trata de produção e validação de conhecimento enquanto atividade eminentemente humana; trata-se de tomar todas as prerrogativas em jogo (o lugar, o conhecimento, a compreensão de seu estar-no-mundo) como prerrogativas eminentemente humanas, configurando a possibilidade e a viabilidade de epistemologias, por vezes, distintas de um marco de pensamento associado a uma tradição centroeuropeia mais familiar à nossa formação científica. Em uma curta formulação: trata-se de supor a capacidade normativa e o rigor de produção e validação de conhecimentos nas epistemologias de nossos Outros.

$\mathrm{O}$ argumento em curso realça que a centralidade do lugar, com base na noção de prefácio, em Glissant, estabelece diálogos, por exemplo, com a apropriação que Patricia Hill Collins faz de Sandra Harding (2019, p. 401-432), em sua exposição sobre critérios de validação em um marco de pensamento de mulheres afro-estadunidenses; a esse respeito, assinalando esse diálogo, na citada argumentação de Hill Collins, seria possível observar duas componentes caras ao problema central deste artigo, neste percurso de 
apropriação do prefácio, no momento em que ela situa a centralidade da experiência de sujeitas(os) negras(os) na construção de conhecimento, assim como o caráter coletivo de validação, seja do trabalho político nesse percurso da experiência à produção de conhecimento sobre o lugar, seja da circulação e partilha desse conhecimento tributário do lugar, entre outros lugares e conhecimentos possíveis. ${ }^{22}$

$\mathrm{Na}$ centralidade de sujeitas(os) cognoscentes e, particularmente, do conhecimento produzido, validado e circulado por sujeitas(os) racializadas(os), é necessário situar uma componente da noção de prefácio, visando a seus usos em análises literárias, nos domínios propostos por este texto: em uma palavra, trata-se de estabelecer um compromisso metodológico de, no corpo de análises literárias, tomar a obra ao centro, em sua condição de produção de conhecimento ou, recorrendo e parafraseando a proposta de Fábio Durão (2015), situar o potencial epistemológico das obras literárias afro-americanas ao centro de esforços de análises literárias, na perspectiva de seu lugar de enunciação.

A centralidade do lugar, a partir da noção de prefácio em Glissant, instaura diálogos, também, com a hipótese de la hybris del punto cero, conforme sua formulação por Santiago Castro-Gómez, em sua circunscrição e crítica a uma posição, recorrente, reivindicatória de neutralidade e objetividade do trabalho científico, o qual, nessa matriz de pensamento acerca do lugar, enfatiza tanto o caráter localizado de qualquer conhecimento quanto a ideia de que essa localização não perfaz, em si mesma, uma insuficiência do conhecimento dela decorrente, o que remete à passagem de Glissant frisando, no texto de $I P D$, que on n'émet pas de paroles dans l'air (Não emitimos palavras ao vento, soltas no ar).

Sob tal perspectiva, se seguirmos a proposição glissantiana, se circunscreve a relevância de uma pergunta, epistemológica, própria a um marco de pensamento descolonial, acerca de uma [auto]suposição de atopia

\footnotetext{
${ }^{22}$ Quando se observa essa possibilidade, dedutível dos textos de Hill Collins e de Glissant, se percebe sua afinidade ao que Pimmer (2017, p. 277) caracteriza como ponto de vista feminista, ressaltando o ganho dessa posiçáo (ao qual, neste momento, se associa, didaticamente, a posição de Glissant) ante uma formulação mais conhecida, de Mignolo, no risco desta última, se levada a suas últimas consequências, conduzir a um determinismo na relação entre lugar e conhecimento: "No sorprende, por lo tanto, que las indagaciones epistemológicas se hayan ocupado más de los problemas de validación del conocimiento que de los sujetos cognoscentes realmente existentes y el respectivo lugar desde el cual emprenden la producción de conocimiento (Harding, 1986; Kim, 1994).” (PIMMER, 2017, p. 277).
} 
da parte de um pensamento centroeuropeu a situar a si mesmo enquanto Ser, enquanto norma, precisamente por uma suposta vantagem epistemológica de sua [também suposta] atopia ante epistemologias localizadas; em diálogo a tal problema, em sua formulação contemporânea, propriamente descolonial, Glissant ressalta le lieu d'où on émet la parole (o lugar de onde emitimos a fala), ao que Castro-Gómez (2007, p. 83) indaga, mediante la hybris del punto cero, a necessidade de demarcar um caráter atópico a determinadas epistemologias em detrimento da localização de outras: "[...] por eso hablamos de la hybris, del pecado de la desmesura. Cuando los mortales quieren ser como los dioses, pero sin tener capacidad de serlo, incurren en el pecado de la hybris, y esto es, más o menos, lo que ocurre con la ciencia occidental de la modernidad." ${ }^{23}$

A centralidade do lugar, a partir da noção de prefácio, em Glissant, estabelece diálogos, igualmente, com um quadro mais amplo de epistemologia de mulheres negras que propóem a necessidade de considerar formaçóes históricas locais, em nossa compreensão de fenômenos americanos, observáveis de modo recorrente; mais precisamente, essa matriz de pensamento de mulheres negras, no desenho desse problema, enseja bases pertinentes a um exame de construçóes identitárias ou, precisamente, de distintos estar-nomundo afro-americanos, de distintos devires afro-americanos, solicitando, como componente a essa noção em jogo, a devida observância às formações históricas locais, com aquilo que se depreende desde cada contexto de violência perceptível no exame de cada lugar americano:

Por isso mesmo, em contraposiçáo aos termos supracitados, eu proponho o de amefricanos ("Amefricans") para designar a todos nós (Gonzalez, 1988c).

[...] Seu valor metodológico, a meu ver, está no fato de permitir a possibilidade de resgatar uma unidade específica, historicamente forjada no interior de diferentes sociedades que se formam numa determinada

\footnotetext{
${ }^{23}$ Esse princípio da hybris del punto cero, estabelecido na formulaçăo de Castro-Gómez, encontra uma antecipação, significativa, por Glissant, no capítulo 37 de $D A$, intitulado "Sur la méthode", mediante a figura do positiviste anxieux (positivista ansioso): "Do ponto de vista metodológico, a intelligentsia martinicana concebeu uma espécie nova: o positivista ansioso. Absolutamente capaz de manipulaçáo técnica, todavia, o positivista ansioso se mostra incapaz de aperfeiçoamento (dépassement) metodológico. Isso porque tomou, como religião, a objetividade dada pela 'ciência'; sente que, aí, reside uma das garantias mais fortes para aceder ao universal, visto que não pode, ele mesmo, suscitar o universal a partir de uma criação contínua de particulares [...] $\mathrm{O}$ positivista ansioso se sente maravilhado nâo apenas das infinitas possibilidades da técnica como, também, de sua justeza. A ordem do mundo o assegura. Sua quantidade de ser equivale a sua quantidade de saber indubitável escapando, assim, ao ambíguo. Sempre haverá uma solução uma vez que o objetivo é." (GLISSANT, 1997, p. 353354 , traduçáo nossa, grifo do autor).
} 
parte do mundo. Portanto, a Améfrica, enquanto sistema etno-geográfico de referência, é uma criação nossa e de nossos antepassados no continente em que vivemos, inspirados em modelos africanos. [...] ontem como hoje, amefricanos oriundos dos mais diferentes países têm desempenhado um papel crucial na elaboração dessa Amefricanidade que identifica, na Diáspora, uma experiência histórica comum que exige ser devidamente reconhecida e cuidadosamente pesquisada. (GONZÁLEZ, 2018, p. 330).

Da aceitação de uma base comum de violência tributária do sequestro, diáspora e escravização negra, nas Américas, não se depreende, todavia, que suas consequências se deem, de modo homogêneo, em todos os lugares amefricanos $^{24}$ : nossos Outros, seus devires, não são homogêneos; dessa aprendizagem partindo da noção de prefácio, abrir-se-ia a possibilidade, metodológica, de construção de saberes científicos sobre a violência, sobre o epistemicídio do modo como se desenha e como se desenvolve em cada lugar amefricano para, em função dessa violência-prefácio, aceder a um conhecimento mais amplo sobre o lugar e sobre a centralidade dessa violência em uma compreensão desse lugar. ${ }^{25}$

Contudo, tal abordagem necessita enfrentar uma acusação de essencialismo identitário atribuída, frequentemente, de forma ampla, às redes constituídas de pensamento amefricano (no que importa a este texto: tanto a sua dimensão ficcional quanto a sua corrente ensaística; tanto à literatura quanto ao pensamento), em um cenário no qual se questionam

\footnotetext{
${ }^{24}$ Doravante, em conformidade a apropriaçôes contemporâneas do pensamento de González e, particularmente, à necessidade [coletiva, por parte de nossa comunidade científica] de operacionalizar a categoria amefricanidade, este artigo adota o termo Améfricas, assim como suas decorrências imediatas (amefricanas(os), lá onde, até aqui, adotáramos "afro-americanas(os)"), assinalando o percurso desse movimento nas pesquisas, em curso, do Projeto de Pesquisa e Extensão Teseu, o labirinto e seu nome.

${ }^{25}$ A importância da violência, nesse tratamento de literaturas amefricanas, poderia ser aproximada da ideia de uma Afro-América ou "América de las plantaciones" (conforme a tipologia de Wagley, acompanhada por Glissant), na qual a plantação se mostra paysage central na observação dessa violência, em um momento atual do debate no qual se revela fundamental recuperar, em nossos marcos conceituais, uma violência por vezes ausente ou insuficiente nos problemas e soluçóes modelares da comunidade científica dos estudos literários, no Brasil, nas últimas duas décadas. A respeito da tipologia de Wagley, ver: GAZTAMBIDE-GEIGEL, 1996; GIRVAN, 1999; acerca da relevância de uma relação entre plantação e violência, em nossas investigaçóes contemporâneas, ver KILOMBA, 2019. Por sua vez, a necessidade de aceder a um conhecimento mais amplo sobre o lugar, assim como sobre a centralidade dessa violência em uma compreensão desse lugar, abriria espaço a outras abordagens metodológicas de investigação de obras literárias não necessariamente centradas em um comparatismo: por exemplo, dentre muitas, a possibilidade de compreensão do lugar mediante estudos de caso, seguida de suas condiçóes de possibilidade a generalizaçōes científicas posteriores (a esse propósito, consultar: GIMÉNEZ, 2012; FLYVBJERG, 2003).
} 
suas legitimidade e literariedade, haja vista seus limites identitários (em sua formulação mais recorrente: identidades supostamente autocentradas, sem possibilidades abertas ao Outro), em oposição a uma literatura e a um pensamento ocidentais supostamente abertos a problemas e propostas relativas a uma totalidade humana. Uma concepção de identidade, amparada em uma interpretação de Glissant, necessita examinar os fundamentos desse gesto duplo de recusa, seja a um corpus de literaturas amefricanas, seja à possibilidade de um marco de pensamento amefricano gozando, efetivamente, do estatuto de pensamento em rede:

\begin{abstract}
Nossos argumentos poderão receber críticas de que mais uma vez estamos voltando à política identitária, que somos metafisicamente não sofisticados e politicamente retrógrados, uma crítica que também tem sido brandida da metrópole para as periferias da academia global. A crítica da política identitária tem mantido muitos "escravos" da acusaçáo de um essencialismo político grosseiro e de falta de sofisticação teórica. Acredito que a inclinaçáo anti-identidade tão prevalente na teoria social hoje é outro obstáculo para o projeto de decolonização do conhecimento, uma vez que isso debilita nossa habilidade de articular o que está errado com a hegemonia teórica do Norte global. (MARTÍN ALCOFF, 2016, p. 136). ${ }^{26}$
\end{abstract}

Uma objeção à ideia mesma de prefácio poderia apontar um essencialismo político como consequência indesejada de uma posição reivindicatória da relaçáo entre lugar e conhecimento - e, de modo mais incisivo, de uma defesa à prerrogativa [eminentemente humana] a qualquer lugar [humano] ser tomado como lugar de conhecimento. O texto de La dissémination, de Jacques Derrida (1972), oferece notas relevantes ao desenvolvimento da noção de prefácio, a partir do texto de $I P D$, ao apontar o risco de concebê-lo como enunciação, no futuro, de sentidos ou conteúdos daquilo que já teria sido previamente escrito (e, portanto, lido):

Une préface rapellerait, annoncerait ici une théorie et une pratique générales de la déconstruction [...] Elle énoncerait au futur ("vous allez lire ceci") le sens ou le contenu conceptuels [...] de ce qui aurait déjà écrit. Donc assez lu pour pouvoir être rassemblé en sa teneur sémantique et d'avance

\footnotetext{
${ }^{26}$ Ademais, a centralidade do lugar à produção, discussão e difusão de conhecimento, as interpretações e apropriaçóes de Glissant, ao longo deste texto, partem de uma pergunta sobre como nossos devires-negros não ocidentais têm sido examinados à luz de epistemologias ocidentais (nas palavras de $O$ local da cultura, a ideia de uma "teoria ocidental"). Como assinala Ochy Curiel Pichardo (2009), a crítica pós-moderna a modelos identitários náo ocidentais tende a ser estabelecida desde um lugar autorreivindicado neutro: "[...] en ese sentido la crítica al esencialismo es válida en tanto permite cuestionar la autenticidad, la naturalización y la homogeneización ubicándolas en contextos históricos." (CURIEL, 2009, p. 26-27).
} 
proposé. Pour l'avant-propos, reformant un vouloir dire après le coup, le texte est un écrit - un passé - que, dans une fausse aparence de présent, un auteur caché et tout-puissant, en pleine maîtrise de son produit, présente au lecteur comme son avenir. Voici ce que j'ai écrit, puis lu, et que j'écris que vous allez lire. Après que vous pourrez reprendre possession de cette préface qu'en somme vous ne lisez pas encore, bien que, l'ayant lue, vous ayez déjà anticipé sur tout ce qui la suit et que vous pourriez presque vous dispensez de lire. Le pré de la préface rend présent l'avenir, le représente, le raproche, l'aspire et en le devançant le met devant. Il le réduit à la forme de présence manifeste. (DERRIDA, 1972, p. 13). ${ }^{27}$

Isso incidiria, do ponto de vista metodológico, em uma ferida de morte: percebendo o prefácio ao lugar amefricano nesses termos, saberíamos, de antemão, o que esperar de cada lugar, de cada construção identitária, de cada estar-no-mundo amefricano, não importando de qual lugar, porque prefácio, o texto seria sempre o mesmo, do que decorreria o risco de uma produçáo de juízos tautológicos sobre o lugar ou, em última instância, a impossibilidade do Divers $^{28}$ próprio a cada lugar amefricano. ${ }^{29}$ Talvez, justamente em abordagens científicas que não tomem em consideração a prerrogativa do Divers próprio a essas literaturas (ou, em sentido mais amplo, das literaturas que racializamos)

${ }^{27}$ Um prefácio, aqui, evocaria, anunciaria uma teoria e uma prática gerais da desconstrução [...] Enunciaria, no futuro ("Você lerá isto"), o sentido ou o conteúdo conceituais [...] do que já teria sido escrito. Portanto, demasiado lido para poder ser apreendido, em seu conteúdo (sua complexidade) semântico posto desde o início. Para um prefácio, reformando um querer dizer após o dito, o texto é um escrito - um passado - que, em sua falsa aparência de presente, um autor oculto e todo-poderoso, em pleno domínio de suas faculdades, se apresenta ao leitor como seu futuro. Eis o que escrevi, depois li, e que [doravante] escrevi, que você [agora] lerá. Quando você se recuperar [retomar a posse] deste prefácio que, ao fim e ao cabo, ainda não leu, á terá antecipado a tudo o que se segue a ponto de, talvez, poder dispensar a leitura. O pré do prefácio mantém presente o porvir, o representa, o aproxima, aspira a ele e o supera, pospondo-o. Ele o reduz à forma de presença manifesta. (DERRIDA, 1972, p. 13, tradução nossa).

${ }^{28} \mathrm{Ou}$, recuperando os termos da $D A$, a transparência de qualquer lugar americano - coerente no interior de um pensamento de sistema em que a transparência de nossos Outros constitui uma de suas premissas.

${ }^{29}$ Isso contradiria a necessidade de considerar o princípio de alteridades históricas (SEGATO, 2007) ou, de forma mais radical, a amefricanidade em suas bases, decorrendo, destarte, uma apreciaçáo ocidental, centroeuropeia, postulando a homogeneidade ou, em termos glissantianos, a transparência de quem tomamos como nossos Outros, de quem apartamos do domínio do Ser: "[...] Seu valor metodológico, a meu ver, está no fato de permitir a possibilidade de resgatar uma unidade específica, historicamente forjada no interior de diferentes sociedades que se formam numa determinada parte do mundo [...] ontem como hoje, amefricanos oriundos dos mais diferentes países têm desempenhado um papel crucial na elaboração dessa Amefricanidade que identifica, na Diáspora, uma experiência histórica comum que exige ser devidamente reconhecida e cuidadosamente pesquisada (GONZÁLEZ, 2018, p. 330).” Esse fragmento da citação anterior de González salienta, justamente, tal ganho metodológico. 
se revele uma faceta do cela se fait couramment (isso se faz a todo instante) assinalado por Derrida, mais adiante; cabe à hipótese do Caribe-prefácio salvaguardar e compreender, precisamente, e desde o princípio, o Divers de cada prefácio ou, mais precisamente, o Divers de cada lugar no gozo de sua prerrogativa a prefaciar o lugar americano elaborando, ao texto americano, perguntas enunciáveis desde cada um de seus distintos lugares possíveis:

[...] il faudrait, dès maintenant, avancer que l'une des thèses - il y a plus d'une - inscrites dans la dissémination, c'est justement l'impossibilité de réduire un texte comme tel à ses effets de de sens, de contenu, de thèse ou de thème. Non pas l'impossibilité, peut-être, puisque cela se fait couramment, mais la résistance - nous dirons la restance - d'une écriture qui ne s'y fait pas plus qu'elle ne se laisse faire. (DERRIDA, 1972, p. 14). ${ }^{30}$

Negar essa possibilidade implica, conforme Derrida, réduire un texte comme tel (um texto como tal, um texto em si), o texto de nossos Outros, a seus efeitos de sentido, a sua imbricação em uma suposta realidade desses Outros - não por acaso, a crítica de que cela se fait couramment; em uma palavra, retomamos algumas das consequências àquilo que se compreende como literariedade, negando-a em textos amefricanos, porque supostamente redutíveis a seus efeitos de sentido, de conteúdo ou de tema. A impossibilidade de redução de um texto a seus efeitos de sentido, de conteúdo, de tese ou de tema acarreta, metodologicamente, pensar essa impossibilidade ao lugar-Caribe ou, por conseguinte, a qualquer lugar amefricano, caso seguida a premissa inicial deste artigo. Importante ressaltar: não a impossibilidade do prefácio, mas a resistência ou, melhor dito, a restance (restência? Restância? O que permanece, o que resta; o que resiste, precisamente, porque em-permanência, malgrado os fluxos?) de uma escritura.

Em tal contexto, abre-se a possibilidade de tomar a restance em textos amefricanos - e, em última instância, que estes gozem da prerrogativa da restance, como cabe a todo discurso humano - como sua impossibilidade de redução [explicativa] a seus efeitos de sentido, de conteúdo, de tese ou

\footnotetext{
30 "[...] a partir de agora, seria preciso avançar a respeito de uma das teses - há mais de uma inscritas na disseminação: justamente, a impossibilidade de reduzir um texto, como tal, a seus efeitos de sentidos, de conteúdo, de tese ou de tema. Talvez não a impossibilidade visto que isso se faz a todo instante, mas a resistência - diríamos, a restance - de uma escritura não se faz mais do que se deixa (do que se permite) fazer." (DERRIDA, 1972, p. 14, tradução nossa).
} 
de tema ${ }^{31}$; por extensão, propóe-se, como princípio norteador das bases à ferramenta metodológica ora discutida, a impossibilidade de redução de textos ficcionais negros (e, analogamente, de textos ficcionais de nossos Outros, por nós racializados) a seus efeitos de raça. Derrida nos auxilia a assinalar que cela se fait couramment em nossos usos da escrevivência ${ }^{32}$, em nossas interpretaçóes de textos literários amefricanos assentadas em uma redução a seus contextos socioeconômicos de emergência, como fator explicativo em sua plenitude, com a consequência última da negação de sua literariedade, dada uma carência de universal, de transcendência, dada a insistência de uma redução de "[...] la chose même (ici, le concept, le sens de la pensée se pensant et se produisant elle-même dans l'élément de l'universalité) à la forme de l'objet particulier, fini [...]" (DERRIDA, 1972, p. 16-17).

No diálogo proposto entre Derrida e Glissant, mais precisamente em uma apropriação da restance como prerrogativa a ficcionalidades amefricanas,

\footnotetext{
${ }^{31}$ A esse respeito, no preâmbulo de sua tese, Fernanda Rodrigues de Miranda inicia a construção de uma premissa fundamental, a perpassar tanto o problema em jogo, neste artigo, quanto uma ideia mesma de literatura (em sua tese, a ideia de literatura brasileira), a saber, nossas dificuldades em perceber ficcionalidades negras como literatura - e esta, por sua vez, como prerrogativa eminentemente humana: "Isto posto, dentro do edifício literário brasileiro, a ideia de uma Literatura Negra instaura uma fratura fundamental, que realinha a ordem epistêmica ao suspender o silenciamento sobre o qual essa obra se sustenta - mantendo a voz do negro em futuros fechados / em furioso silêncio [verso do poema "Sol e blues", de Beatriz Nascimento]. Como ideia, a literatura negra congrega uma potência irredutível de ruptura, porque mescla em um sintagma dois nominativos que a racionalidade eurocêntrica não concebe em paralelo: como já foi dito por inúmeros pensadores negros e antirracistas, diferente do que acontece com 'música negra', 'arte negra', 'dança negra', etc., a 'literatura negra' causa incômodo e reação porque deliberadamente posiciona o negro como sujeito da escrita.” (MIRANDA, 2019, p. 13; grifo da autora).
}

32 Precisamente ante este problema, verifica-se, nos últimos anos, um crescimento, quantitativo e qualitativo, de investigaçóes que retmam, sistematizam e operacionalizam a noçáo de escrevivência, tal como formulada na ensaística e na ficção de Conceição Evaristo, de modo a propor novas apropriaçóes de um corpus de literaturas negras brasileiras criticamente posicionado ante uma tendência, [ainda] circulante na comunidade científica dos Estudos Literários (puisque cela se fait couramment), de reduzir ficcionalidades negras à ses effets de de sens, de contenu, de thèse ou de thème, em uma violência observável quando a abordagem científica nega a résistance - nous dirons la restance - a textos ficcionais negros (ou, em sentido mais amplo: racializados) em nome de seu caráter supostamente tautológico, perfazendo um cenário no qual a complexidade da escrevivência seria reduzida a poéticas limitadas e explicáveis, sempre e apenas, só e somente só, mediante uma realidade socioeconômica diretamente descrita desde uma perspectiva biográfica, por vezes circunscrita sob o termo "a realidade de pessoas negras". Negandolhes a restance, nega-se-lhes a literariedade. A passagem da restance ao lugar nos permite compreender a escrevivência como noção própria a um campo semântico do lugar, em um marco de pensamento amefricano contemporâneo (e, portanto, inserida no debate ora proposto). Quanto aos avanços da comunidade científica dos estudos literários, no Brasil, em seus esforços coletivos de apropriação e operacionalização da escrevivência, convém destacar, como publicação recente: DUARTE; NUNES, 2020. 
pode-se identificar uma componente da noção de prefácio, rumo a uma abordagem metodológica a essas literaturas: a restance própria ao texto literário (ainda que pareça um juízo evidente em um marco de teoria literária, cumpre assinalar, no âmbito deste argumento: a restance própria a textos literários que racializamos), a serviço de uma compreensão do que se assinala como pensamento negro contemporâneo, a qual recorrem noçóes operatórias como o prefácio (Glissant), a escrevivência (EVARISTO, 2005; 2020), a malungaje (BRANCHE, 2013).

Isso implica que, desde o princípio, é necessário circunscrever cada lugar a se prefaciar desde dentro, desde si, em um grande texto americano. A reivindicação da hipótese de um "grande texto americano" prepara o terreno a uma noção suplementar, cara ao pensamento de Glissant: o droit à l'Opacité (direito à Opacidade). O prefácio passa a operar não mais como exterioridade, mas como enunciação; não mais fora, pré- ou antes, mas desde, ante e para (rumo a) o texto. Ganho complementar: torna-se possível enunciar o lugar americano desde cada lugar possível a seu Divers. O droit à l'Opacité repousa sobre a constatação de complexidades próprias a cada lugar ou, em última instância, seu gozo à prerrogativa dessa complexidade; de modo coerente ao sistema glissantiano, esse princípio de Opacité reivindica a possibilidade, aberta, de compreensão e de trocas permanentes entre o lugar e os demais lugares possíveis ao Tout-monde. Nessa possibilidade de produção e difusão de conhecimento, eis a noção de Opacité, "[...] partindo da premissa de que as trocas e fluxos culturais contemporâneos se mostram possíveis sob um princípio de Relação, em vez de uma homogeneização ou redutibilidade a um princípio definido como universal.” (ALVES, 2019).

\section{O PRINCÍPIO DO DROIT À L'OPACITÉ}

Acerca da importância epistemológica do lugar, nos termos discutidos, convém aportar a hipótese de Homi K. Bhabha (2005), ao apresentar a possibilidade de construçóes identitárias "de outro modo que não a modernidade" - especificamente, um modelo centroeuropeu de modernidade; não obstante, convém cotejá-la com a proposta de Glissant, em $D A$, no que esta abre espaço ao droit à l'Opacité: além de estabelecer os limites a um conceito de compreensão, recorda-nos nossa própria posição científica, desde um modelo de ciência ocidental, sempre com o risco de tomar a sujeitas(os) de estudo como seu Outro, renovando um ciclo de violência epistêmica: 
Nous réclamos le droit à l'opacité. Par quoi notre tension pour tout dru exister rejoint le drame planétaire de la Relation: l'élan des peuples néantisés qui opposent aujourd'hui à l'universel de la transparence, imposée par l'Occident, une multiplicité sourde du Divers. Un tel travail est spectaculaire partout dans le monde où les tueries, les génocides impavides, les assauts d'épouvante tâchent de liquider la précieuse résistance des peuples. Il est inaperçu quand il s'agit de communautés vouées à une plus ou moins confortable disparition en tant que telles. (GLISSANT, 1997, p. 14-15)..$^{33}$

\section{O lugar, no pensamento de Glissant, pode contribuir com a manutenção} de uma vigilância epistemológica quanto ao risco de uma ciência totalizante de seu objeto, em que a ciência que desempenhamos se converte, frequentemente, em veículo de l'universel de la transparence, imposée par l'Occident (universal da transparência, imposto pelo Ocidente); uma vigilância epistemológica quanto aos limites de nossa compreensão de sujeitas(os) e lugares cujo estar-no-mundo parte, por vezes, quiçá mais frequentemente do que nossa ciência esteja disposta a aceitar, de epistemas outros que não o ocidental. Ganho complementar: a partir da noção de prefácio, circunscreve-se a pergunta pela legitimidade do lugar como uma pergunta política, interessando à análise perguntar de onde cada lugar enuncia, assim como suas significaçóes pelas(os) próprias(os) sujeitas(os). ${ }^{34} \mathrm{~A}$ estas(es) e, por extensão, a lugares racializados, a [aqueles que

\footnotetext{
33 "Reclamamos o direito à opacidade, pelo qual nossa tensão (nosso empenho, nossa gana) por, vigorosamente, existir, alcança ao drama planetário da Relação: o elá (o impulso) dos povos nadificados que, hoje, se opóem ao universal da transparência, imposto pelo Ocidente, uma multiplicidade surda do Diverso. Tal tarefa se faz espetacular, por toda parte, neste mundo em que assassinatos, genocídios impávidos, ataques terroristas tratam da preciosa resistência dos povos. Passa despercebido quando se trata de comunidades, como tais, destinadas a um desaparecimento mais ou menos confortável." (GLISSANT, 1997, p. 14-15, tradução nossa). A expressão tout dru necessita, além de uma proposta de tradução (aqui: o advérbio vigorosamente; ao que, igualmente, caberia veementemente), de uma nota explicativa, pois, em vez de se tratar de um problema de digitaçáo ou de editoração, constitui uma sofisticaçáo argumentativa à Opacité, destacando, na agência de sujeitas(os) fora do Ocidente, "[...] nossa tensão (nosso empenho, nossa gana) por, vigorosamente, [a despeito do] universal da transparência, imposto pelo Ocidente." Aqui se recorre ao apoio da tradução de $D A$ para o espanhol, na qual, como soluçáo a tout dru, se adotara con reciedumbre (GLISSANT, 2010). Por sua vez, a proposta de nadificados, como solução a neantisés, se inspira no conto "Los nadies" (GALEANO, 1989, p. 52), de sorte a destacar uma componente cara à violência em jogo: sua imposiçáo, assim como seu caráter exógeno (ao que se recorre ao particípio, em vez de um substantivo a evocar uma essência a estas(es) sujeitas(os) a quem se violenta.
}

${ }^{34}$ No que tange à legitimidade do lugar como uma pergunta política, poderíamos situar a noção de encruzilhada e, particularmente, seus usos como base metodológica [afim ao prefácio], a subsidiar análises literárias, consolidada em teses recentes fundamentais à comunidade científica dedicada às literaturas negras contemporâneas, no Brasil, notadamente desde seus usos de partida nas teses de 
tomamos como] nossos Outros, peuples néantisés (povos nadificados), nós lhes negamos a restance, de maneira que todo [aquele tomado como] Outro tende a ser compreendido, necessariamente, de modo cíclico - ensejando, em determinados contextos de análise literária, perguntar a que(m) serve a deslegitimação da enunciação desde certos lugares, particularmente aqueles racializados de modo exógeno.

A presente apropriação da noção de prefácio, mediante recurso ao droit à l'Opacité ou, em paráfrase aos termos derridianos, um "droit à la restance", necessita reivindicar, como prerrogativa ao texto negro, sua condição de texto eminentemente humano. Negá-la, sob tais condiçóes, mediante essas justificaçôes subjacentes, assinala um gesto de violência (um epistemicídio) nos fundamentos de nossas análises literárias sobre textualidades amefricanas - porque autoexplicativas, tautológicas, desprovidas de uma restance própria à natureza de todo texto eminentemente humano. Esse percurso, rumo à proposição de componentes válidas a uma apropriação metodológica da noção de prefácio, permite retomar um problema legítimo (delineado no início deste

Fernanda Miranda e de Fernanda Felisberto. Quanto à primeira, reivindica-se a encruzilhada desde o primeiro período argumentativo de sua tese, em nome de ficcionalidades [em sua própria expressão] férteis como terra preta, em uma associação riquíssima entre a terra e o pensamento: "O primeiro ponto a ser firmado é que essa tese parte da encruzilhada - plurilugar que de partida estanca a possibilidade indesejada da via única. Encruzilhando autorias, teorias e áreas do conhecimento, a fim de abarcar um conjunto inaudito e fugidio de textos literários, abrem-se caminhos na leitura. $\mathrm{O}$ objetivo que move este trabalho é o de contribuir com os estudos em torno da escrita de autoria negra no Brasil, trazendo o gênero romance para o centro da observação. Especificamente, os romances escritos por autoras negras brasileiras. Trata-se de um tema pouco abordado, sobre o qual serão necessárias ainda muitas pesquisas, tanto voltadas à análise de cada obra singular quanto à própria configuração do corpus e às possibilidades de leituras comparativas que ele oferece dentro da literatura em língua portuguesa e para a literatura mundial.” (MIRANDA, 2019, p. 11). A riqueza metodológica da encruzilhada como passagem, partida, mapa em certo sentido, se apresenta na exposiçáo de Felisberto: "Ao longo da história da população negra no Brasil a encruzilhada tem sido um elemento metafórico, que permite a pesquisadoras(es) e interessadas(os) na temática entender como alguns processos históricos foram engendrados em suas trajetórias." (SILVA, 2011, p. 20). Sua formulação toma de empréstimo a Leda Martins, ao propor a cultura negra [diríamos, neste momento, em uma perspectiva amefricana] como uma cultura das encruzilhadas, estendendo esta noção "[...] para além das fronteiras geográficas nacionais e também engloba as Américas, já que foram regióes importantes de recepção de africanas(os) escravizadas(os)." (SILVA, 2011, p. 20). Do ponto de vista metodológico, importante salientar que, em ambas as teses, a encruzilhada - assim como o prefácio, nos termos deste artigo - abrem a possibilidade de estudos frequentes, porém, não exclusivamente comparativos, de modo a vislumbrar diálogos com distintas abordagens metodológicas a textos literários amefricanos (não necessariamente, mas frequentemente, comparatistas, onde Miranda propóe análises "[...] tanto voltadas à análise de cada obra singular quanto à própria configuração do corpus e às possibilidades de leituras comparativas", ao passo que, para Felisberto, "as encruzilhadas citadas anteriormente como marca da cultura negra brasileira e da diáspora africana estaráo presentes no corpo desta tese de doutorado, já que definimos como metodologia principal de trabalho o comparativismo." (SILVA, 2011, p. 21). 
texto) a partir de, doravante, a inserção de uma terceira premissa, ao que listamos: a) a agência dessas(es) sujeitas(os) em condição de subalternidade; b) a subalternidade compreendida, não como essência, mas enquanto condição atribuída a sujeitas(os) e coletividades humanas; ao que acrescentamos c) a atribuição de uma condição de subalternidade a sujeitas(os) e coletividades humanas traz, em sua base, um gesto de violência imputada a essas(es) sujeitas(os). ${ }^{35}$

A noção de Divers, assim como a evocação do droit à l'Opacité, oferece instrumentos para salvaguardar a restance no exame dos distintos lugares de enunciação amefricanos (e daquilo que nos cabe: seu exame, mediante interpretação das obras literárias deles tributárias), implicando que lugares por nós racializados, [aqueles tomados como] nossos Outros, eles como nós, gozamos da prerrogativa da iterabilidade. Significamos a marca. Trazemos a marca. Cabe assinalar que a presença da marca náo garante, nela mesma, a possibilidade de que sujeitos signifiquem ${ }^{36}$, do que decorre nossa predisposição a uma escuta visando a compreender cada lugar, no gozo de suas prerrogativas de produção de conhecimento sobre si e sobre seu devir. ${ }^{37}$

\footnotetext{
${ }^{35}$ Conforme o referencial teórico de abordagem comparativa a um corpus de literaturas americanas, essa violência em c) se habilitaria a constituir uma componente do prefácio, de maneira a receber tratamento posterior rumo à formulaçáo de indicadores e de índices textuais a estabelecer uma ferramenta metodológica de análises literárias, conforme os fins visados neste texto. A respeito desse percurso metodológico de tratamento de componentes (ou dimensóes) de noçóes e conceitos, em pesquisas científicas, consulte-se: LAZARSFELD, 1973; CORTÉS, RUBALCAVA, 1993.
}

${ }^{36}$ Sobre os limites próprios a essa posição epistemológica específica, a qual, em sua relação entre lugar e conhecimento, oferece o risco de uma consequência determinista [indesejada], limites esses associados ao conceito de lugar em Mignolo, consulte-se: PIMMER, 2017. Sobre os termos desse debate a uma prerrogativa da iterabilidade em ficcionalidades amefricanas, no interior de nossa comunidade científica, consulte-se: ALVES, 2014.

${ }^{37}$ Ao debater o problema do lugar de enunciação (ou, recorrendo à noção de Conceição Evaristo, circulante no atual momento da comunidade científica: da escrevivência), a possibilidade de conhecimento por parte de sujeitas(os) e coletividades amefricanas quiçá não possa ser reduzida a um conceito clássico de experiência. A esse propósito, cumpre salientar que Patricia Hill Collins, na recente tradução brasileira de Pensamento feminista negro (2019), sugere parâmetros à compreensão de uma noçáo de experiência ou, mais precisamente, da experiência (vivida, coletivamente, por mulheres afroestadunidenses) como critério de significado, centrando sua abordagem no exame de processos de validação de conhecimento. Nesses termos, um exame mais detido das condiçóes a uma experiência assim validada (ou, em outros termos: o tributo da palavra ao lugar), mediante recurso ao texto de Hill Collins, oferece meios para constituir uma componente válida a essa noção de prefácio, em sua suposição de que cada lugar goza das prerrogativas de a) dizer o lugar americano e b) partilhar da produção e validação coletiva de conhecimento sobre o lugar americano. 
Heiddeger distingue entre as categorias do ôntico e do ontológico (Heidegger, 2002). O ôntico se refere aos entes particulares, ou às determinaçốes do ser. Ontológico diz respeito ao ser enquanto tal. Entáo, raça, cor, cultura, religiáo e etnia seriam da ordem do ôntico, das particularidades do ser. Ser, e especificamente Ser Humano, inscreve-se na dimensão ontológica. O que nos permite supor que o racismo reduz o ser a sua dimensão ôntica, negando-lhe a condição ontológica, o que lhe atribui incompletude humana. (CARNEIRO, 2005, p. 28).

No quadro do debate proposto, a apropriação que Sueli Carneiro efetua de uma passagem de Ser e tempo contribui a uma compreensão dos processos de racialização de sujeitas(os) negras(os). A crítica ao lugar, quando referida a sujeitas(os) negras(os) enquanto sujeitas(os) cognoscentes, se revela pertinente na construção de um problema legítimo, sobretudo ao constatar que ao Sujeito (conforme Sueli Carneiro: aquele que goza da prerrogativa da dimensão ontológica) compete discutir qualquer tema de conhecimento, de si ou de seus Outros, ao passo que a estes lhes restaria uma posição de objeto de ciência (os micróbios no microscópio, na imagem clássica de Luiz de Aguiar Costa Pinto) ${ }^{38}$, uma posição tautológica (tanto na construção de problemas modelares quanto de soluçóes modelares), uma dimensão ôntica. ${ }^{39}$ A sequência de sua apropriação oferece subsídios a uma compreensão, por extensão, de um risco, o de racializar o lugar de nossos Outros, assim como o

\footnotetext{
${ }^{38}$ Trata-se de uma alusão ao debate estabelecido entre Costa Pinto e Abdias do Nascimento, a partir da imagem do micróbio no microscópio, proposta pelo primeiro, no I Congresso Brasileiro do Negro, em 1959: a referida imagem enseja um dos pontos centrais a este texto, a saber, a disputa em torno da posição de sujeito cognoscente ou, em termos mais radicais, a interdição de uma posição cognoscente a sujeitas(os) racializadas(os), notadamente a sujeitas(os) negras(os). A esse respeito, ver: MAIO, 1997. Para uma primeira abordagem à posição clássica de Alberto Guerreiro Ramos sobre sujeitas(os) negras(os) circunscritos a tema de investigaçôes científicas, consulte-se: GUERREIRO RAMOS, 1954; BARIANI, 2008.

${ }^{39}$ Ademais de Sueli Carneiro, a tese de Luís Carlos Ferreira dos Santos apresenta outro exemplo, fundamental aos fins deste artigo, em sua exposiçấo de como Glissant avança sobre o pensamento de Heidegger, de sorte a propor uma poética propriamente desde o lugar, em Philosophie de la Relation: “Glissant (2009) pergunta: 'O que é isto, uma filosofia?', a pergunta difere de como Martin Heidegger (1973) coloca a pergunta: 'Que é Isto - A Filosofia?' A filosofia é uma poética, de acordo com Glissant, uma poética dos arquipélagos, pois ela é territorializada e busca ser não totalitária, pelo fato de agenciar as paisagens em uma teia de relaçóes. A poética carrega as sombras das florestas e detém o brilho da memória das terras, traz como característica a penetração do obscuro e atua como um eco das particularidades e da totalidade." (SANTOS, 2019, p. 182). Ambas as teses, a de Carneiro e a de Santos, oferecem perspectivas de pensamento amefricano que, sem se limitar ao exame de uma matriz filosófica centroeuropeia, no Brasil, se mostram propositivas em seu estabelecimento de bases filosóficas propriamente amefricanas, habilitando à formulação de problemas modelares sob bases amefricanas.
} 
conhecimento tributário desse lugar, exigindo, de nossa parte, uma vigilância epistemológica a seu respeito:

É a idéia de universalidade que emancipa o indivíduo e permite-lhe expressar a sua diversidade humana. Em contrapartida, é a idéia de particularidade que aprisiona o indivíduo, ou seja, na temática desta tese, é a reduçáo do ser à sua particularidade que aprisiona o indivíduo nãoocidental ao seu grupo específico. É nossa compreensão que, ao fazer do ôntico o ontológico do Outro, o Eu hegemônico rebaixa o estatuto do ser desse Outro. (CARNEIRO, 2005, p. 28-29).

Quiçá a construção de um problema modelar novo, na senda de uma epistemologia da ciência literária, diga respeito ao problema de sujeitas(os) negras(os) [e, no limite, a quem tomamos como nossos Outros] enquanto sujeitas(os) cognoscentes ${ }^{40}$, com os desdobramentos da legitimidade a) da literariedade de literaturas negras; b) da cientificidade de problemas modelares acerca de literaturas negras; assim como c) da legitimidade de investigadoras(es) negras(os) enquanto parte da comunidade científica.

\section{Consideraçóes Finais}

De modo a propor um epílogo ao presente texto, convém situar a importância da contribuiçáo de Glissant, nessa formulação inicial de princípios metodológicos (mais precisamente, a proposição de componentes válidas à noção de prefácio) a um exame de literaturas amefricanas, incidindo sobre o valor epistemológico do lugar e, notadamente, do Divers próprio a cada lugar amefricano, assim como aos modos de sua compreensáo, mediante exame científico das literaturas tributárias de cada um desses lugares possíveis. Trata-se de investigar os limites próprios a uma ciência literária, no que tange a suas possibilidades de compreensão de um corpus de literaturas amefricanas.

As possibilidades abertas pela importância epistemológica do lugar, desde os aportes de Glissant, assinalam a prerrogativa de sujeitas(os) [por nós] racializadas(os) a enunciar desde uma posição determinada, portadora de tempo e lugar (como qualquer outra), sem que isso lhe implique demérito ou ferida de morte; implicando, igualmente, que destes tempo e lugar não

${ }^{40}$ Talvez, nesse sentido, convenha examinar a proposta de uma epistemología del sujeto conocido, assim como algumas de suas consequências a nossas metodologias de investigação de sujeitas(os) e comunidades que tomamos como nossos Outros; para tanto, consulte-se: VASILACHIS DE GIALDINO, 2009. 
decorrem, absolutamente, uma condição de inferioridade epistêmica. Desse estabelecimento de inferioridade depende, visceralmente, a ideia de uma superioridade de Ocidente (Centroeuropa e Estados Unidos) ante quaisquer outras posiçóes-de-sujeito. ${ }^{41} \mathrm{O}$ Ocidente, porque universal, não se refere a posição alguma e, por conseguinte, não se evidencia acometível da fraqueza natural[izada] de uma posição:

Quando iniciei a pesquisa, acreditei que me seria possível fazer um estudo sobre gênero em uma comunidade iorubá contemporânea, que principalmente abordaria a questáo a partir de uma abordagem local. Logo ficou nítido para mim que, em função da prática acadêmica de depender de teorias e debates conceituais originados e dominados pelo Ocidente, muitas das questóes que orientaram o projeto de pesquisa inicial não foram (e não poderiam ser) gerados nas condiçóes locais. Mas segui acreditando que o problema poderia ser superado durante o processo. (OYĚWÙMÍ, 2021).

A citação de $A$ invenção das mulheres, de Oyèrónkẹ́ Oyěwùmí, assinala os riscos e consequências científicas do Sujeito (em maiúscula, nos moldes da crítica de Spivak a um quadro de pós-estruturalismo francês), ao falar por seu objeto, incidindo em uma delimitação exógena de seu ser. Interpreta-se o epistemicídio, nesses termos, não apenas como um gesto de dominação em moldes militares ou econômicos, porém, igualmente, em seu papel relativo a uma economia politica do conhecimento (CUSICANQUI, 2010; CURIEL, 2019); a introdução de Oyěwùmí, nestas consideraçōes finais, ajuda a compreender esse problema no cerne de nosso fazer-ciência, assim como as possibilidades de um marco de pensamento negro contemporâneo, ao aportar novas perspectivas ao problema da relação entre lugar e conhecimento: no escopo deste texto, perspectivas metodológicas a um exame de literaturas amefricanas.

${ }^{41}$ Uma vez mais, cumpre assinalar a preferência à definição de Ocidente proposta por Glissant em $D A$, em detrimento à de Mignolo, dadas as consequências deterministas anteriormente citadas (conforme nosso acordo a PIMMER, 2017). Em Glissant, “[...] l'Occident n'est pas à l'ouest. Ce n'est pas un lieu, c'est un projet” (o Ocidente não está a oeste; não é um lugar [geográfico], mas um projeto [político]) (1997, p. 14). 
ALVES, A. C. Hypotheses about Édouard Glissant's preface notion. Trans/Form/Açáo, Marília, v. 45, p. 207-238, 2022. Edição Especial.

\begin{abstract}
Caribbean as a preface to the Americas, according to the essay Introduction à une poétique du Divers, by Édouard Glissant, understanding it in a frame of American black thought. The apropriation of Glissant's premise aims to propose bases for a methodological tool, based on the epistemological centrality of the place, subsidizing literary analyzes among a corpus of Afro-American literatures. This text, initially, starts from the hypothesis that any African-American national literature (including Afro-Brazilian literature) can be taken, in a sparing way, as a preface to a broader corpus of African-American literature.
\end{abstract}

Keywords: Édouard Glissant: theory. Preface. Place. African-American literature.

\title{
REFERÊNCIAS
}

ALEXIS, J. S. Do realismo maravilhoso dos haitianos. In: Antologia de textos

fundadores do comparatismo literário interamericano. Tradução de Normelia Parise. Comentário de Maximilien Laroche. s.d. Disponível em: https:/www.ufrgs.br/cdrom/ alexis/index.htm. Acesso em: 06 jul. 2021.

ALVES, A. C. Mulheres deixam traços nas águas? Organon (UFRGS), Porto Alegre, v. 29, n. 57, p. 77-98, jul./dez. 2014. Disponível em: https://seer.ufrgs.br/organon/article/ view/48291. Acesso em: 25 jan. 2021.

ALVES, A. C. Violência epistêmica, redes intelectuais, sujeitas(os) cognoscentes. In: ENCONTRO NACIONAL DA ANPOLL, XXXIII., Produção de conhecimento, liberdade intelectual e internacionalização: homenagem ao Prof. Antonio Candido. 2018. Cuiabá-MT. Anais [...] Cuiabá-MT: UFMT, Campus de Cuiabá, 2018. Disponível em: http://anpoll.org.br/eventos/enanpoll2018/wp-content/uploads/2018/06/Artigo-AnpollAlcione-Enanpoll.pdf\#page=15\&zoom=auto,-89,755. Acesso em: 25 jan. 2021.

BARIANI, E. Niger Sum: Guerreiro Ramos, o "problema” do negro e a sociologia do preconceito. Perspectivas, São Paulo, v. 34, p. 193-211, jul./dez. 2008. Disponível em: https://periodicos.fclar.unesp.br/perspectivas/article/view/2243/1848. Acesso em: 25 jan. 2021.

BHABHA, H. K. O local da cultura. Tradução de Myriam Ávila, Eliana Lourenço de Lima Reis, Gláucia Renate Gonçalves. 3. reimpr. Belo Horizonte: Ed. da UFMG, 2005 (Coleção Humanitas). 
BRANCHE, J. Malungaje: Hacia una poética de la diáspora africana. In: WALSH, C. Pedagogías decoloniales: prácticas insurgentes de resistir, (re)existir y (re)vivir. Tomo I. Quito: Abya-Yala, 2013, p. 165-187 (Série Pensamiento Descolonial).

\section{CARNEIRO, A. S. A construçáo do outro como náo-ser como fundamento do ser.} 2005. 339f. Tese (Doutorado em Educação) - Linha de Pesquisa: Filosofia e Educação, Universidade de São Paulo, São Paulo, 2005.

CARPENTIER, A. Prólogo. El reino de este mundo. 4. ed. Montevideo: Arca, 1969. p. 7-14 (Narrativa Latinoamericana, 2).

CASTRO-GÓMEZ, S. Decolonizar la universidad. La hybris del punto cero y el diálogo de saberes. In: CASTRO-GÓMEZ, S.; GROSFOGUEL, R. (ed.). El giro decolonial. Reflexiones para una diversidad epistémica más allá del capitalismo global. Bogotá: Siglo del Hombre, 2007. p. 79-91.

CORTÉS, F.; RUBALCAVA, R. M. Consideraciones sobre el uso de la estadística en las ciencias sociales: estar a la moda o pensar un poco. In: MENDEZ, I.; CASANOVA, P. G. (coord..). Matemáticas y Ciencias Sociales. Ciudad de México: CEIICH-UNAM y Miguel Ángel Porrúa, 1993. p. 227-267.

CURIEL, O. Las paradojas de la política de la identidad y de la diferencia. In: Derecho, interculturalidad y resistencia étnica. Bogotá: Universidad Nacional de Colombia. Facultad de Derecho, Ciencias Políticas y Sociales. Instituto Unidad de Investigaciones Jurídico-Sociales Gerardo Molina (UNIJUS), 2009, p. 21-28.

CUSICANQUI, S. R. Ch'ixinakax utxiwa: una reflexión sobre prácticas y discursos descolonizadores. 1. ed. Buenos Aires: Tinta Limón, 2010 (Tinta Limón).

DERRIDA, J. La dissémination. Paris: Éditions du Seuil, 1972.

DEVÉS-VALDÉS, E. Introducción: la noción “redes intelectuales” y su significado para los estudios eidológicos y para pensar el futuro intelectual latinoamericano. In: Redes intelectuales en América Latina. Hacia la constitución de una comunidad intelectual. Santiago: IDEA-USACH, 2007. p. 29-36 (Coleccion Idea. Segunda Época). Disponível em: http://www.cecies.org/imagenes/edicion_408.pdf. Acesso em: 25 jan. 2021.

DEVÉS-VALDÉS, E. Prefácio. In: Pensamiento periférico. Ásia-África-América LatinaEurasia y algo más. Una tesis interpretativa global. Ciudad Autónoma de Bunos Aires: CLACSO; IDEA-USACH, 2014. p. 12-21. Disponível em: http://biblioteca.clacso.edu. ar/clacso/se/20140217024434/PensamientoPeriferico.pdf. Acesso em: 25 jan. 2021.

DUARTE, E. de A. Por um conceito de literatura afro-brasileira. Terceira margem:

Revista do Programa de Pós-graduação em Ciência da Literatura, Universidade Federal do Rio de Janeiro, ano XIV, n. 23, p. 113-138, jul./dez. 2010.

DURÃO, F. A. Reflexôes sobre a metodologia de pesquisa nos estudos literários. DELTA [on-line], v. 31, n. spe, p. 377-390, 2015. Disponível em: http://www.scielo.br/scielo. php?pid=S0102-44502015000300015\&script=sci_abstract\&tlng=pt. Acesso em: 25 jan. 2021. 
EVARISTO, C. Gênero e etnia: uma escre(vivência) de dupla face. In: MOREIRA, N.; SCHNEIDER, L. (org.). Mulheres no mundo: etnia, marginalidade, diáspora. João Pessoa: Ideia; Editora Universitária - UFPB, 2005. p. 201-212.

EVARISTO, C. A Escrevivência e seus subtextos. In: Escrevivência: a escrita de nós: reflexôes sobre a obra de Conceição Evaristo. Organização de Constância Lima Duarte e Isabella Rosado Nunes; ilustrações Goya Lopes. Rio de Janeiro: Mina Comunicação e Arte, 2020. p. 26-46.

FLYVBJERG, B. Making Social Science Matter. Cambridge: Cambridge University Press, 2003.

FONSECA, M. N. S. Literatura negra, literatura afro-brasileira: como responder à polêmica? In: SOUZA, F.; LIMA, M. (org.). Literatura afro-brasileira. Salvador: Centro de Estudos Afro-Orientais; Brasília: Fundação Cultural Palmares, 2006. p. 9-37.

GALEANO, E. Los nadies. In: El libro de los abrazos. 1. ed. Ciudad Autónoma de Buenos Aires: Siglo XXI; Catálogos, 1989. p. 52.

GAZTAMBIDE-GEIGEL, A. La invención del Caribe en el siglo XX. Las definiciones del Caribe como problema histórico y metodológico. Revista Mexicana del Caribe, v. 3, n. 7, 1996, p. 74-96, 1996.

GIMÉNEZ, G. El problema de la generalización en los estudios de caso. Revista Cultura y representaciones sociales. Ańo 7, n. 13, p. 40-61, 2012.

GIRVAN, N. Reinterpretar el Caribe. Revista Mexicana del Caribe, v. 7, p. 6-34, 1999.

GLISSANT, É. Beyond Babel. World Literature Today, v. 63, n. 4, p. 561-564, 1989.

Disponível em: www.jstor.org/stable/40145542. Acesso em: 3 jul. 2021.

GLISSANT, É. Introduction à une poétique du Divers. Paris: Gallimard, 1996.

GLISSANT, É. Le discours antillais. Paris: Gallimard, 1997.

GLISSANT, É. Introdução a uma poética da diversidade. Tradução de Enilce do Carmo Albergaria Rocha. Juiz de Fora: Editora UFJF, 2005 (Coleçáo Cultura, v. 1).

GLISSANT, É. Haïti, point focal de la Caraïbe. Caraïbes: un monde à partager. Notre Librairie: revue des littératures d'Afrique, des Caraïbes et de l'océan Indien. Cultures Sud, Paris, n. 168, p. 28-30, mar. 2008.

GLISSANT, É. El discurso antillano. Prólogo de J. Michael Dash. Traducción de Aura Marina Boadas, Amelia Hernández y Lourdes Arencibia Rodríguez. La Habana: Fondo Editorial Casa de las Américas, 2010 (Colección Nuestros Países - Serie Estudios).

GLISSANT, É. O Mesmo e o Diverso; Técnicas. In: Antologia de textos fundadores do comparatismo literário interamericano. Tradução de Normelia Parise. Comentário de Graciela Ortiz. s. d. Disponível em: https://www.ufrgs.br/cdrom/glissant/index.htm. Acesso em: 25 jan. 2021. 
GONZÁLEZ, L. A categoria político-cultural da Amefricanidade. In: GONZÁLEZ, L. Primavera para as rosas negras: Lélia González em primeira pessoa... Diáspora Africana: Filhos da África, 2018. p. 321-334.

GUERREIRO RAMOS, A. O problema do negro na sociologia brasileira. Cadernos de Nosso Tempo, v. 2, n. 2, p. 189-220, jan./jun. 1954. Disponível em: http:/www. schwartzman.org.br/simon/negritude.htm. Acesso em: 21 jan. 2021.

HALL, S. Nascimento e morte do sujeito moderno. In: A identidade cultural na pósmodernidade. Tradução de Guacira Lopes Louro. 11. ed. Rio de Janeiro: DP\&A, 2006.

HALL, S. Onde está o "sujeito”? In: Cultura e representaçáo. Tradução de Daniel Miranda e William Oliveira. Rio de Janeiro: Editora PUC-Rio: Apicuri, 2016. p. 98-107.

HENRY, P. Introduction. In: Caliban's reason: introducing Afro-Caribbean philosophy. New York: Routledge; London: Routledge; Taylor \& Francis e-Library, 2002. p. 1-20.

HILL COLLINS, P. Epistemologias negras feministas. In: Pensamento feminista negro. Tradução de Jamille Pinheiro Dias. São Paulo: Boitempo, 2019. p. 401-432.

hooks, b. Negritude pós-moderna. In: Anseios: raça, gênero e políticas culturais. Tradução de Jamille Pinheiro. São Paulo: Elefante, 2019. p. 70-85.

KUHN, T. S. A prioridade dos paradigmas. In: A estrutura das revoluçóes científicas. Tradução de Beatriz Vianna Boeira e Nelson Boeira. 5. ed. Sáo Paulo: Perspectiva, 1998. p. 67-76 (Debates).

LAZARSFELD, P. De los conceptos a los índices empíricos. In: LAZARSFELD, P.; BOUDON, R. Metodología de las ciencias sociales: conceptos e índices. Barcelona: Laia, 1973. p. 35-46. (Tomo 1).

MAIO, M. C. Uma polêmica esquecida: Costa Pinto, Guerreiro Ramos e o tema das relações raciais. Dados, Rio de Janeiro, v. 40, n. 1, 1997. Disponível em: http://www. scielo.br/scielo.php?script=sci_arttext\&pid=S0011-52581997000100006\&lng=en\&nrm= iso. https://doi.org/10.1590/S0011-52581997000100006. Acesso em: 21 jan. 2021.

MARTÍN ALCOFF, L. Uma epistemologia para a próxima revolução. Sociedade e Estado [online], v. 31, n. 1, p. 129-143, 2016. Disponível em: https://www.redalyc.org/ articulo.oa?id=339945647007. Acesso em: 21 jan. 2021.

MIRANDA, F. R. de. Corpo de romances de autoras negras brasileiras (18592006): posse da história e colonialidade nacional confrontada. 2019. Tese (Doutorado em Estudos Comparados de Literaturas de Língua Portuguesa) - Faculdade de Filosofia, Letras e Ciências Humanas, Universidade de São Paulo, São Paulo, 2019. doi:10.11606/T.8.2019.tde-26062019-113147. Disponível em: https:/www.teses.usp.br/ teses/disponiveis/8/8156/tde-26062019-113147/pt-br.php. Acesso em: 07 jul. 2021.

OYĚWÙMÍ, O. Prefacio. In: A invençáo das mulheres. Construindo um sentido africano para os discursos ocidentais de gênero. Tradução de Wanderson Flor do Nascimento; posfácio de Cláudia Miranda. 1. ed. Rio de Janeiro: Bazar do Tempo, 2021. 
PIMMER, S. El pensamiento y su lugar: consideraciones epistemlógicas en torno al punto de vista feminista y el pensamiento fronterizo. Tabula Rasa. Bogotá - Colombia, n. 27, julio-diciembre 2017, p. 275-299, jul./dez. 2017. Disponível em: https://doi. org/10.25058/20112742.452. Acesso em: 21 jan. 2021.

PORTO, M B. V. Paisagens da insularidade: a poética do exíguo na literatura antilhana de língua francesa. Revista Brasileira do Caribe, Goiânia, v.VI, n. 12, p. 339-369, jan./jun. 2006. Disponível em: http://www.periodicoseletronicos.ufma.br/index.php/ rbrascaribe/article/view/7566. Acesso em: 06 jul. 2021.

SAID, E. W. Cultura e imperialismo. Tradução de Denise Bottman. São Paulo: Companhia das Letras, 1995.

SEGATO, R. L. Raza es signo. In: La Nación y sus Otros: raza, etnicidad y diversidad religiosa en tiempos de políticas de la identidad. Buenos Aires: Prometeo Libros, 2007. p. 131-150.

SILVA, F. F. da. Escrevivências na Diáspora:escritoras negras, produção editorial e suas escolhas afetivas, uma leitura de Carolina Maria de Jesus, Conceição Evaristo, Maya Angelou e Zora Neale Hurston. 2011. 154 f. Tese (Doutorado em Literaturas de Língua Inglesa; Literatura Brasileira; Literatura Portuguesa; Língua Portuguesa; Ling) Universidade do Estado do Rio de Janeiro, Rio de Janeiro, 2011. Disponível em: http:// www.bdtd.uerj.br/handle/1/6077. Acesso em: 07 jul. 2021. Acesso em: 21 jan. 2021.

SILVA-REIS, D. Sobre a guianidade literária de expressão francesa: prelúdio temático.

Communitas, [S. 1.], v. 5, n. 10, p. 79-92, 2021. Disponível em: https://periodicos.ufac. br/index.php/COMMUNITAS/article/view/4984. Acesso em: 06 jul. 2021.

SOUSA SOBRINHO, E. C. Três ensaios traduzidos: Édouard Glissant em crítica afrodiaspórica. 2019. 101f. (Programa de Pós-Graduação em Literatura e Cultura) Universidade Federal da Bahia, Salvador, 2019. Disponível em: https://repositorio.ufba. br/ri/handle/ri/29267. Acesso em: 06 jul. 2021.

SOUZA, L. M. N. Uma reflexão sobre os discursos menores ou a escrevivência como narrativa subalterna. Revista Crioula, v. 21, p. 25-43, 2018. Disponível em: http://www. revistas.usp.br/crioula/article/view/146551. Acesso em: 06 jul. 2021.

SOUZA, L. C. F. O poder de matar e a recusa em morrer: filopoética afrodiaspórica como arquipélago de libertação. 2019. 236f. (Doutorado Multi-institucional e Multidisciplinar em Difusão do Conhecimento - Faculdade de Educação) - Universidade Federal da Bahia, Salvador, 2019. Disponível em: https://repositorio.ufba.br/ri/handle/ ri/30575. Acesso em: 25 jan. 2021.

SPIVAK, G. C. Pode o subalterno falar? Tradução de Sandra Regina Goulart Almeida, Marcos Pereira Feitosa e André Pereira Feitosa. Belo Horizonte: EdUFMG, 2010. 
ALVES, A. C.

VASILACHIS DE GIALDINO, I. Los fundamentos ontológicos y epistemológicos de la investigación cualitativa. Forum Qualitative Sozialforschung/Forum: Qualitative Social Research, v. 10, n. 2, Art. 30, 2009. Disponível em: http://nbn-resolving.de/ urn:nbn:de:0114-fqs0902307. Acesso em: 25 jan. 2021.

Recebido: 29/8/2020

Aceito: 22/12/2020 